\title{
Effect of Rice Hull Mulch on Nutrient Concentration of Fertilized Irrigation Water
}

\author{
James E. Altland ${ }^{1}$ \\ USDA-ARS, Application Technology Research Unit, 27 Horticultural Insects \\ Research Lab., 1680 Madison Avenue, Wooster, OH 44691
}

Jennifer K. Boldt
USDA-ARS, Application Technology Research Unit, Greenhouse Production
Research Group, 2801 W. Bancroft Street, Mail Stop 604, Toledo, OH 43606

Additional index words. nitrate, phosphate, potassium, sunflower, plant nutrition

\begin{abstract}
Parboiled rice hulls (PBH) have been shown to be an effective mulch for weed control in container crops. As with other mulch products, there is concern that $\mathbf{P B H}$ mulch would interfere with nutrient delivery to the crop. The objective of this research was to determine the effect of $\mathrm{PBH}$ mulch on nutrient concentration of fertilized irrigation water as it passes through the mulch layer, and the subsequent effect on growth and nutrition of container-grown sunflower (Helianthus annuus). Parboiled rice hull mulch was placed in Buchner funnels at a depth of $0,0.63,1.25$, or $2.50 \mathrm{~cm}$. Irrigation was applied with a water-soluble fertilizer $(20 \mathrm{~N}-4.4 \mathrm{P}-16.6 \mathrm{~K})$ injected at a concentration of $100 \mathrm{mg} \cdot \mathrm{L}^{-1} \mathrm{~N}$. Filtrates were collected after passing through the PBH in the Buchner funnels and analyzed for nutrient concentration. In a separate study, sunflower in no. 3 containers were mulched with the same depths of PBH and irrigated with water fertilized similar to that in the funnel experiment. Parboiled rice hull mulch caused a temporary and slight decrease in $\mathrm{NO}_{3}{ }^{-}$and $\mathrm{NH}_{4}{ }^{+}$concentration. Phosphate and $\mathrm{K}^{+}$concentrations generally increased with each irrigation event. Calcium and $\mathrm{Mg}$ exhibited an inverse relationship where the $\mathrm{PBH}$ mulch decreased $\mathrm{Ca}$ and increased $\mathrm{Mg}$ concentrations in the filtrates. Despite these measured differences in the chemical properties of water passing through the mulch layer, there were no measurable differences in sunflower growth or physical appearance, and only minor and inconsequential differences in plant nutrient status. Rice hull mulches are likely to have very minor effects on container crop nutrition with no adverse effect on plant growth over a 6 week production cycle as used in this experiment.
\end{abstract}

Numerous mulch products have been evaluated for use in container crops. Pine bark nuggets have been shown to provide effective control of mulberry weed [Fatoua villosa (Thunb.) Nakai] (Penny and Neal, 2003), prostrate spurge (Chamaesyce maculata L.), eclipta (Eclipta alba L. Hassk) (Cochran et al., 2009), bittercress (Cardamine spp.), and oxalis (Oxalis stricta L.) (Richardson et al., 2008). In each of the aforementioned studies, weed control was shown to improve with increasing depth of pine bark mulch. Wilen et al. (1999) showed that composted greenwaste, pecan [Carya illinoinensis (Wangenh.) K. Koch] shells, and pine (Pinus taeda L.) bark at a depth of $2.5 \mathrm{~cm}$ provided excellent control of creeping woodsorrel (Oxalis corniculata L.), northern willow herb (Epilobium ciliatum Raf.), and common groundsel (Senecio vulgaris L.), but only moderate to poor control of annual bluegrass (Poa annua L.). Ferguson et al. (2008) showed that a $3.7 \mathrm{~cm}$ layer of wood chip mulches from southern redcedar [Juniperus

Received for publication 17 May 2017. Accepted for publication 11 July 2017.

${ }^{1}$ Corresponding author. E-mail: James.Altland@, ARS.USDA.GOV.

Krause, 2014), a similar concern of N immobilization was voiced by nursery growers (J. Altland, personal observations, unpublished). In a review of mulch use in urban landscapes, Chalker-Scott (2007) explained that high carbon to nitrogen ratio $(\mathrm{C}: \mathrm{N})$ is incorrectly assumed by many practitioners to immobilize fertilizer $\mathrm{N}$ and thus deprive plants of sufficient nutrients. Chalker-Scott (2007) goes on to assert that mulches do not affect nutrition of landscape plants. There are numerous experiments in field soils that support this assertion and show mulches do not adversely affect nutrient uptake of field-grown crops (Broschat, 2007; Ram et al., 2003; Trinka and Pritts, 1992). However, this generalization about interactions between mulch and fertilizer in field crops might not be applicable to container crops. Altland and Lanthier (2007) reported that container-grown hydrangea [Hydrangea macrophylla (Thunb.) Ser. 'Fasan'] with controlled release fertilizer (CRF) placed below the mulch were larger and had higher foliar $\mathrm{N}$ concentration compared with those with CRF placed above the mulch. The implication was that $\mathrm{N}$ from $\mathrm{CRF}$ placed above the mulch was partially immobilized by the mulch layer. Likewise, Glenn et al. (2000) showed that recycled paper mulch reduced petunia (Petunia floribunda Hort. 'Midnight Madness' and $P$. grandiflora Hort. 'Ultra Blue') growth and leachate $\mathrm{N}$ when CRF was placed above the mulch layer. The objective of this research was to determine specifically how PBH mulch affects the nutrient concentration of irrigation water passing through the mulch layer, and subsequently how this affects substrate and plant nutrition.

\section{Materials and Methods}

silicicola (Small) E. Murray] and southern magnolia (Magnolia grandiflora L.) provided control of redroot pigweed (Amaranthus retroflexus L.) and large crabgrass [Digitaria sanguinalis (L.) Scop.].

Parboiled rice hulls have been shown to provide excellent control of flexuous bittercress (Cardamine flexuosa With.), liverwort (Marchantia polymorpha L.) (Altland and Krause, 2014), and creeping woodsorrel (Oxalis corniculata L.) (Altland et al., 2016a). Parboiled rice hulls prevent establishment of new weed seed by drying quickly following irrigation, resulting in insufficient moisture to support germination and establishment of new weeds. Parboiled rice hulls are less effective in preventing germination of weed seed preexisting on the substrate surface before mulch application. To prevent germination and establishment of preexisting weed seed, a sufficient mass must cover the substrate surface to physically impede germination $\left(>500 \mathrm{~g} \cdot \mathrm{m}^{-2}\right.$ or a depth of $\left.1.25 \mathrm{~cm}\right)$ (Altland et al., 2016).

A common concern about organic mulches is that they impose nitrogen $(\mathrm{N})$ deficiency on crops they surround. After initial reports on the utility of $\mathrm{PBH}$ for weed control in container crops (Altland and
Direct measurement of filtrates. Twopiece, PVC Buchner funnels $(13.1 \mathrm{~cm}$ i.d., $6.6 \mathrm{~cm}$ tall, Fisher Scientific, Waltham, MA) were randomly assigned to receive $\mathrm{PBH}$ (Riceland Foods, Inc., Stuttgart, $\mathrm{AK}$ ) at a depth of $0,0.63,1.25$, or $2.50 \mathrm{~cm}$. It was established that $2.5 \mathrm{~cm}$ depth of $\mathrm{PBH}$ weighed $44 \mathrm{~g}$ so that replicate funnels could be uniformly mulched by weighing $0,11,22$, or $44 \mathrm{~g}$ of $\mathrm{PBH}$ for the $0,0.63,1.25$, or 2.50 $\mathrm{cm}$ treatments, respectively. Funnels were placed on a greenhouse bench equipped with an overhead irrigation system and fixed pattern nozzles (Rain Bird 5H; Rain Bird Corp., Azusa, CA). Funnels received overhead irrigation consisting of city tap water injected (D14MZ2; Dosatron International Inc., Clearwater, FL) with a commercial complete fertilizer with micronutrients (Jack's $20 \mathrm{~N}-4.4 \mathrm{P}-16.6 \mathrm{~K}-0.15 \mathrm{Mg}-0.02 \mathrm{~B}-$ $0.01 \mathrm{Cu}-0.1 \mathrm{Fe}-0.05 \mathrm{Mn}-0.01 \mathrm{Mo}-0.05 \mathrm{Zn}$; JR Peters, Inc., Allentown, PA) at a concentration of $100 \mathrm{mg} \cdot \mathrm{L}^{-1} \mathrm{~N}$. Each funnel was placed over a $400 \mathrm{~mL}$ glass jar (Fisher Scientific) so that the fertilized irrigation water passing through the mulch layer would collect in the jar beneath, and furthermore, only water passing through the funnel (and no other extraneous irrigation water) would enter into 
the jar. The irrigation system was run for 10 min per day, resulting in an application of $\approx 1.3 \mathrm{~cm}$ of water. About $30 \mathrm{~min}$ after irrigation ceased, the fertilized irrigation water that filtered through the mulch was collected from the jars beneath each funnel. Samples were filtered through GF/F binderfree borosilicate glass fiber filter paper (Whatman Ltd., Kent, UK) to remove particles greater than $0.7 \mu \mathrm{m}$. The filtrate was poured into $5 \mathrm{~mL}$ autosampler vials, capped, and analyzed using ion chromatography (ICS 1600 Ion Chromatography System; Dionex, Bannockburn, IL) for concentrations of nitrate $\left(\mathrm{NO}_{3}{ }^{-}\right)$, ammonium $\left(\mathrm{NH}_{4}^{+}\right)$, phosphate $\left(\mathrm{PO}_{4}{ }^{3-}\right)$, potassium $(\mathrm{K})$, calcium $(\mathrm{Ca})$, magnesium $(\mathrm{Mg})$, and sulfate $\left(\mathrm{SO}_{4}{ }^{2-}\right)$. There were six replications per mulch depth arranged on a single bench in a completely randomized design. Samples were collected daily for nine days, excluding weekends. This experiment was repeated.

Effect on plant growth. Sunflower (Helianthus annuus L. 'Sunbright') seeds (Ball Horticultural Co., West Chicago, IL) were sowed on 2 Aug. 2016 into 50-cell trays filled with a soilless substrate composed of 85 peatmoss : 15 perlite. On 23 Aug. 2016, when sunflowers were $\approx 8 \mathrm{~cm}$ tall, they were transplanted into $11.4 \mathrm{~L}$ containers (No.3; Nursery Supplies, Chambersburg, PA) filled with a 60 pine bark : 40 peatmoss substrate amended with $1.8 \mathrm{~kg} \cdot \mathrm{m}^{-3}$ dolomitic lime (ECOPHRST, National Lime and Stone Co., Findlay, $\mathrm{OH})$. The substrate surface of each container was covered with $0,0.63,1.25$, or $2.50 \mathrm{~cm}$ of PBH. It was established that a $2.50 \mathrm{~cm}$ layer of $\mathrm{PBH}$ weighed $132 \mathrm{~g}$, thus PBH mulch layers of uniform depth were added to the containers by applying $0,33,66$, or $132 \mathrm{~g}$ of $\mathrm{PBH}$ for 0 , $0.63,1.25$, and $2.50 \mathrm{~cm}$ mulch treatments, respectively. Plants were grown in a glasscovered greenhouse in Wooster, $\mathrm{OH}$, with natural photoperiod and heat and cool setpoints at 24 and $27{ }^{\circ} \mathrm{C}$, respectively. Containers were irrigated with the same water and fertilizer as in the previous study; however, it was applied through spray stakes (Yellow, 11.4 L per h, Netafim, Fresno, CA) rather than overhead nozzles to distribute the water over the substrate or mulch surface and avoid contact with foliage. Irrigation was run twice daily for $1 \mathrm{~min}$ each cycle, so that each plot received $\approx 1 \mathrm{~cm}$ of water per day.

One-third of the plants in each treatment was randomly selected and harvested each at 2, 4, and 6 weeks after potting (WAP). At harvest, foliar relative chlorophyll content was determined with a chlorophyll meter (Minolta-502 SPAD meter; Spectrum Technologies, Inc., Plainfield, IL) by taking a measurement on five recently matured leaves per plant and recording the mean for each experimental unit. Recently matured foliage was harvested for foliar nutrient with deionized water, then oven dried at $55^{\circ} \mathrm{C}$ for $3 \mathrm{~d}$. Samples were ground in a mill (Tecator Cyclotec AB, Hogenas, Sweden) through a $0.5 \mathrm{~mm}$ screen. Foliar nitrogen analyses (Mills and Jones, 1996), rinsed
(N) was determined by measuring $\approx 2.5 \mathrm{mg}$ of dry tissue into tin capsules (Costech Analytical, Valencia, CA) and analyzing with a CHNS/O Perkin Elmer Elementar Analyzer (PerkinElmer, Waltham, MA). Other macronutrients and micronutrients were determined by first processing samples with microwave digestion (MARS 6; CEM Corp., Matthews, NC), then injection in an optical emission spectrometer (iCAP 6300 Duo). The elemental content of PBH was also determined by subjecting five unused samples to the same preparation and analyses as the sunflower tissue samples.

Immediately after leaf tissue harvests, shoot dry weight (SDW) was determined by removing the aboveground portion of the plant, oven drying at $55{ }^{\circ} \mathrm{C}$ for $3 \mathrm{~d}$, and weighing. Substrates were analyzed for $\mathrm{pH}$, electrical conductivity (EC), and water extractable nutrients using a modified saturated media extraction procedure (Warncke, 1986). Substrate from the center of the root ball was transferred to a $400 \mathrm{~mL}$ glass jar.
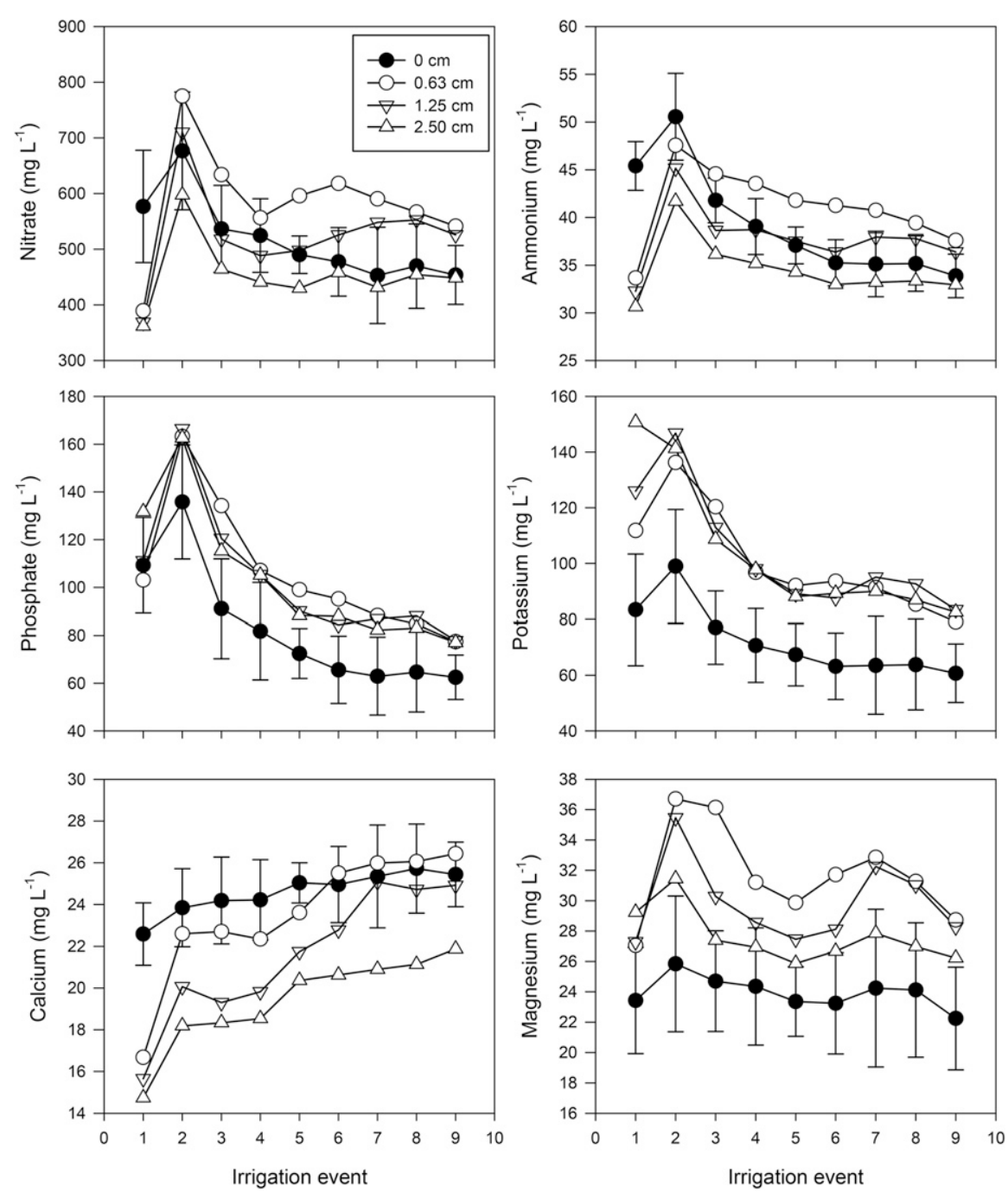

Fig. 1. Concentrations of nitrate, ammonium, phosphate, potassium, calcium, and magnesium in fertilizerinjected irrigation water passing through $0,0.63,1.25$, or $2.50 \mathrm{~cm}$ deep layer of parboiled rice hull mulch. The irrigation water was injected with a water-soluble fertilizer $(20 \mathrm{~N}-4.4 \mathrm{P}-16.6 \mathrm{~K})$ at $100 \mathrm{mg} \cdot \mathrm{L}^{-1} \mathrm{~N}$ (Expt. 1). Bars around the nonmulched control means represent the minimum significant difference from the Dunnett's $t$ test.

Reverse osmosis (RO) water was added to the point of saturation. The substrate slurry was allowed to come to equilibrium for $24 \mathrm{~h}$. Afterward, the liquid phase of the slurry was Fisher Scientific) fitted with a fiberglass filter paper (G6, Thermo Fisher Scientific). The Buchner funnels were attached to an Buer flask and placed under vacuum substrate and through the filter paper. Solution $\mathrm{pH}$ was determined with a $\mathrm{pH} /$ ion analyzer (MA 235; Metler Toledo, Colum, $\mathrm{OH})$ and $\mathrm{EC}$ with a conductivity mete tific). Samples were subsequently filtered through GF/F binder-free borosilicate glass fiber filter paper (Whatman Ltd.) to remove particles greater than $0.7 \mu \mathrm{m}$. The filtrate was and analyzed using ion chromatography (ICS 1600) for concentrations of $\mathrm{NO}_{3}^{-}, \mathrm{NH}_{4}^{+}$, $\mathrm{PO}_{4}{ }^{3-}, \mathrm{K}, \mathrm{Ca}, \mathrm{Mg}$, and $\mathrm{SO}_{4}{ }^{2-}$. Micronutrient funnel $(13.1 \mathrm{~cm}$ i. $6.6 \mathrm{~cm}$ tall, Therm

HortScience Vol. 52(9) September 2017 
(Fe, $\mathrm{Mn}, \mathrm{Cu}, \mathrm{B}, \mathrm{Mo}$, and $\mathrm{Zn}$ ) concentrations were determined with optical emission spectrometry (iCAP 6300 Duo View ICP-OES Spectrometer; Thermo Fisher Scientific). Six replications per mulch treatment were harvested each at 2, 4, and 6 WAP. Plants were arranged on a single greenhouse bench in a completely randomized design.

Data from both experiments were subjected to analysis of variance (ANOVA) using statistical software (SAS v9.3; SAS Institute, Cary, NC). Regression analysis was used to determine the significance of linear or quadratic responses to mulch depth. Means were separated with Dunnett's least significant difference test (Figs. 1 and 2) and Fisher's protected least significant difference test (Tables 1 and 2).

\section{Results and Discussion}

Direct measurement of filtrates. Repeated measures analysis showed a significant time by mulch depth interaction for each of the six nutrients analyzed in Expt. $1(P<0.0075)$ and Expt. $2(P<0.0302)$ (data not shown). Nitrate concentrations were lower in filtrates from all mulched funnels compared with the nonmulched control after the first irrigation event in Expt. 1 (Fig. 1). Funnels with $2.50 \mathrm{~cm} \mathrm{PBH}$ had filtrate $\mathrm{NO}_{3}{ }^{-}$concentrations lower than the nonmulched control at the fourth and fifth irrigation events, but similar concentrations on all other dates. On the second and subsequent irrigation events, funnels with 0.63 and $1.25 \mathrm{~cm}$ mulch had similar or greater $\mathrm{NO}_{3}{ }^{-}$concentrations than the nonmulched control. Nitrate concentrations fluctuated less over time in Expt. 2 (Fig. 2). In Expt. 2, $\mathrm{NO}_{3}{ }^{-}$ concentrations from funnels with $2.50 \mathrm{~cm}$ $\mathrm{PBH}$ were less than nonmulched controls on the sixth irrigation event only. Otherwise, $\mathrm{NO}_{3}{ }^{-}$concentrations from all mulched funnels were similar or greater than nonmulched controls throughout the experiment.

Ammonium concentration in filtrates from mulched funnels was lower than the nonmulched control at the first irrigation event in Expt. 1 (Fig. 1). Funnels with 0.63, 1.25 , and $2.50 \mathrm{~cm} \mathrm{PBH} \mathrm{mulch} \mathrm{had} \mathrm{similar} \mathrm{or}$ higher $\mathrm{NH}_{4}{ }^{+}$concentrations than the nonmulched control by the second, fourth, and sixth irrigation event, respectively. In Expt. $2, \mathrm{NH}_{4}{ }^{+}$concentrations from mulched funnels were lower than the nonmulched control through the third irrigation event. All treatments were similar with respect to $\mathrm{NH}_{4}{ }^{+}$ concentration on the fourth irrigation event. From the fifth irrigation event and to the end of the experiment, $\mathrm{NH}_{4}{ }^{+}$concentrations in funnels mulched with $2.50 \mathrm{~cm} \mathrm{PBH}$ were lower than nonmulched controls.

The target $\mathrm{N}$ concentration in the irrigation water was $100 \mathrm{mg} \cdot \mathrm{L}^{-1} \mathrm{~N}\left(60 \% \mathrm{NO}_{3}^{-}-\mathrm{N}\right.$ and $\left.40 \% \mathrm{NH}_{4}{ }^{+}-\mathrm{N}\right)$. This concentration and proportion of $\mathrm{N}$ forms should have resulted in 265 $\mathrm{mg} \cdot \mathrm{L}^{-1} \mathrm{NO}_{3}{ }^{-}$and $51 \mathrm{mg} \cdot \mathrm{L}^{-1} \mathrm{NH}_{4}^{+}$. Nitrate levels were generally higher and $\mathrm{NH}_{4}{ }^{+}$levels were lower than expected in nonmulched controls for both experiments. Only the deepest mulch layer of $2.50 \mathrm{~cm}$ sporadically
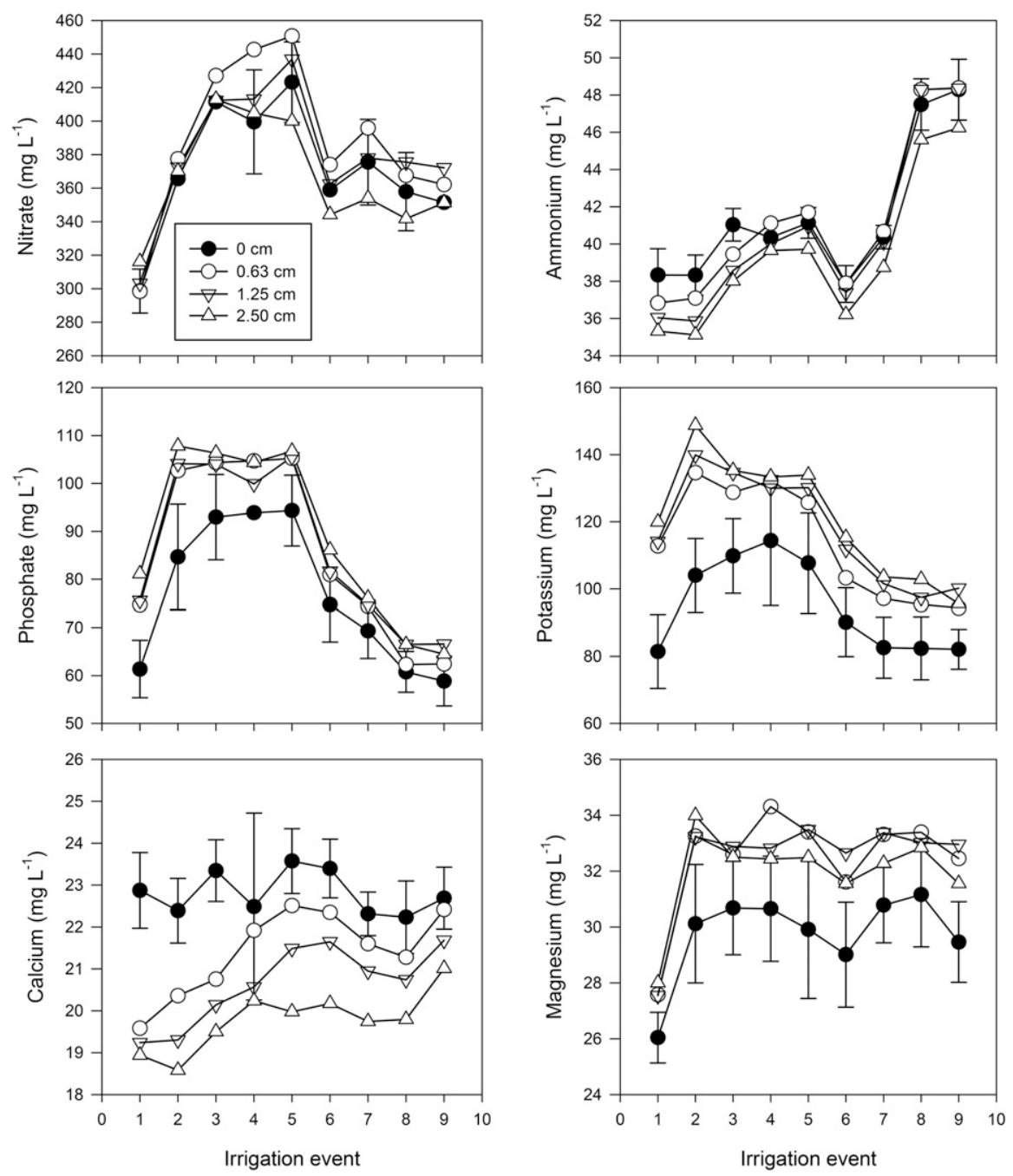

Fig. 2. Concentrations of nitrate, ammonium, phosphate, potassium, calcium, and magnesium in fertilizerinjected irrigation water passing through $0,0.63,1.25$, or $2.50 \mathrm{~cm}$ deep layer of parboiled rice hull mulch. The irrigation water was injected with a water-soluble fertilizer $(20 \mathrm{~N}-4.4 \mathrm{P}-16.6 \mathrm{~K})$ at $100 \mathrm{mg} \cdot \mathrm{L}^{-1} \mathrm{~N}$ (Expt. 1). Bars around the nonmulched control means represent the minimum significant difference from the Dunnett's $t$ test.

reduced $\mathrm{NO}_{3}{ }^{-}$or $\mathrm{NH}_{4}{ }^{+}$concentrations. Gachukia and Evans (2008) reported slightly increasing $\mathrm{NO}_{3}{ }^{-}$and decreasing $\mathrm{NH}_{4}{ }^{+}$concentrations in leachates from substrates with increasing $\mathrm{PBH}$ percentages immediately after mixing peat and $\mathrm{PBH}$ substrate blends.

Phosphate concentration in filtrates from funnels mulched $2.50 \mathrm{~cm}$ was higher than the nonmulched controls on the first irrigation event, whereas all other mulched funnels were similar to the nonmulched control (Fig. 1). By the second irrigation and throughout the experiment, all mulched funnels had higher $\mathrm{PO}_{4}{ }^{3-}$ concentrations than the nonmulched control. A similar trend occurred in Expt. 2. All mulched funnels had higher $\mathrm{PO}_{4}{ }^{3-}$ concentrations than the nonmulched control through the first five irrigation events. Thereafter, only funnels with $2.50 \mathrm{~cm}$ PBH had a consistently higher $\mathrm{PO}_{4}{ }^{3-}$ concentration than the nonmulched control. Elevated $\mathrm{PO}_{4}{ }^{3-}$ concentrations in mulched funnels were expected. Parboiled rice hulls contained $0.06 \% \mathrm{P}$ on a dry weight basis (Table 1), of which $83 \%$ was water-soluble
Table 1. Nutrient content of parboiled rice hulls used for mulch, on a dry weight basis (mean and SD, $n=5$ ).

\begin{tabular}{lc}
\hline & $(\%)$ \\
\hline $\mathrm{N}$ & $0.31 \pm 0.06$ \\
$\mathrm{P}$ & $0.06 \pm 0.01$ \\
$\mathrm{~K}$ & $0.17 \pm 0.01$ \\
$\mathrm{Ca}$ & $0.07 \pm 0.01$ \\
$\mathrm{Mg}$ & $0.05 \pm 0.00$ \\
\hline
\end{tabular}

and released from the PBH within $4 \mathrm{~d}$ (Altland et al., 2016b). Likewise, Evans et al. (2011) reported water-extractable $\mathrm{P}$ concentrations from 60 to $130 \mathrm{mg} \cdot \mathrm{L}^{-1}$ over the course of $56 \mathrm{~d}$ from parboiled $\mathrm{PBH}$ of varying particle size.

Potassium concentration of filtrates was lower in the nonmulched control than all mulched funnels throughout both experiments, with the exception of irrigation 4 in Expt. 2 (Figs. 1 and 2). Similar to $\mathrm{PO}_{4}{ }^{3-}$, high $\mathrm{K}^{+}$concentrations in the filtrates from mulched funnels were expected because of contributions from $\mathrm{PBH}$. The $\mathrm{K}^{+}$concentration of $\mathrm{PBH}$ used in this experiment was 
$0.17 \%$ of dry mass (Table 1 ), of which $88 \%$ was water soluble in the first $5 \mathrm{~d}$ (Altland et al., 2016).

Calcium concentration in filtrates was higher in the nonmulched control than all other mulched funnels on the first irrigation event (Fig. 1). Funnels with 0.63 and $1.25 \mathrm{~cm}$ PBH were similar to the nonmulched control by irrigation 2 and 7, respectively. Calcium concentration from funnels with $2.5 \mathrm{~cm} \mathrm{PBH}$ remained lower than the nonmulched control throughout the experiment. A similar trend occurred in Expt. 2, with respect to $\mathrm{Ca}^{2+}$ concentration being suppressed in mulched funnels (Fig. 2). Funnels with $0.63 \mathrm{~cm} \mathrm{PBH}$ were eventually similar to nonmulched controls at irrigation 4 and 7, whereas those with 1.25 and $2.50 \mathrm{~cm} \mathrm{PBH}$ remained lower than the nonmulched control throughout the study.

Magnesium was lower in filtrates of the nonmulched control compared with filtrates from mulched funnels (Figs. 1 and 2). Throughout Expt. 1 and 2, the nonmulched control had a similar $\mathrm{Mg}^{2+}$ concentration to funnels with $2.50 \mathrm{~cm}$ PBH (with a few sporadic exceptions), whereas those with 0.63 or $1.25 \mathrm{~cm}$ generally had higher $\mathrm{Mg}^{2+}$ concentrations than the nonmulched control. The effect of mulch depth on
$\mathrm{Ca}^{2+}$ and $\mathrm{Mg}^{2+}$ concentrations seems to be inversely related. Calcium is more tightly bound to cation exchange sites than $\mathrm{Mg}^{2+}$ because of its greater atomic radius. It is possible that as $\mathrm{Ca}^{2+}$ from the fertilizer solution was retained by the $\mathrm{PBH}$ mulch, it displaced $\mathrm{Mg}^{2+}$ ions, thus the net effect was reduced $\mathrm{Ca}^{2+}$ and increased $\mathrm{Mg}^{2+}$ in filtrates passing through the PBH mulch.

Effect on plant growth. Sunflower foliar SPAD readings increased from week 1 to week $6(P<0.0001)$, but were unaffected by treatment within any give date $(P>0.1487)$ nor the interaction between time and treatment $(P=0.4389)$. Sunflower height was similar across treatments at each of the three harvest dates $(P>0.2118)$. Likewise, sunflower shoot dry weights were also similar at each harvest date across treatments $(P>$ $0.4339)$. Rice hull mulch depth had no effect on plant growth or appearance (SPAD foliar chlorophyll). By the conclusion of the experiment, plant height averaged $118 \mathrm{~cm}$ and flower buds were just beginning to form.

Substrate $\mathrm{pH}$ was affected by mulch treatment at 2 and 4 WAP, but not 6 WAP (Table 1). At $2 \mathrm{WAP}$, substrates with $2.50 \mathrm{~cm}$ mulch had the highest $\mathrm{pH}$, whereas at $4 \mathrm{WAP}$ nonmulched containers had the highest $\mathrm{pH}$. The difference between the highest and lowest $\mathrm{pH}$ within each date was at most 0.5 $\mathrm{pH}$ units. Dole and Wilkins (1999) recommend $\mathrm{pH}$ to be $6.0-6.5$, and warn that $\mathrm{pH}$ below 5.5 can result in $\mathrm{Mg}$ or Fe toxicity. Substrate $\mathrm{pH}$ was below 5.5 in all treatments for at least one of the harvest dates, yet no signs of nutrient toxicity were observed.

Substrate EC levels were affected by treatment at 2 and $6 \mathrm{WAP}$, but not $4 \mathrm{WAP}$ (Table 1). In both cases the nonmulched control treatment had slightly higher EC than containers with $1.25 \mathrm{~cm}$ mulch. At $6 \mathrm{WAP}$, the nonmulched controls were also higher than containers with $0.63 \mathrm{~cm}$ mulch. Such minor differences do not likely reflect important nutritional differences in the substrates.

Water-extractable $\mathrm{NO}_{3}{ }^{-}$concentrations decreased linearly with increasing mulch depth at 2 WAP (Table 2). There were no differences in substrate $\mathrm{NO}_{3}{ }^{-}$concentration at 4 WAP. By 6 WAP, there was a quadratic response to increasing $\mathrm{PBH}$ depth, and the nonmulched controls had greater waterextractable $\mathrm{NO}_{3}^{-}$concentrations than all other substrates. Water-extractable $\mathrm{NH}_{4}^{+}$ levels were low or undetectable throughout

Table 2. Substrate $\mathrm{pH}$, electrical conductivity (EC), and concentration of nitrate, phosphate, potassium, calcium, and magnesium in the saturated media extract of substrates covered with $0,0.63,1.25$, or $2.50 \mathrm{~cm}$ of parboiled rice hull mulch. Substrates were from destructively harvested containers at 2,4 , and 6 weeks after potting [week after potting (WAP)].

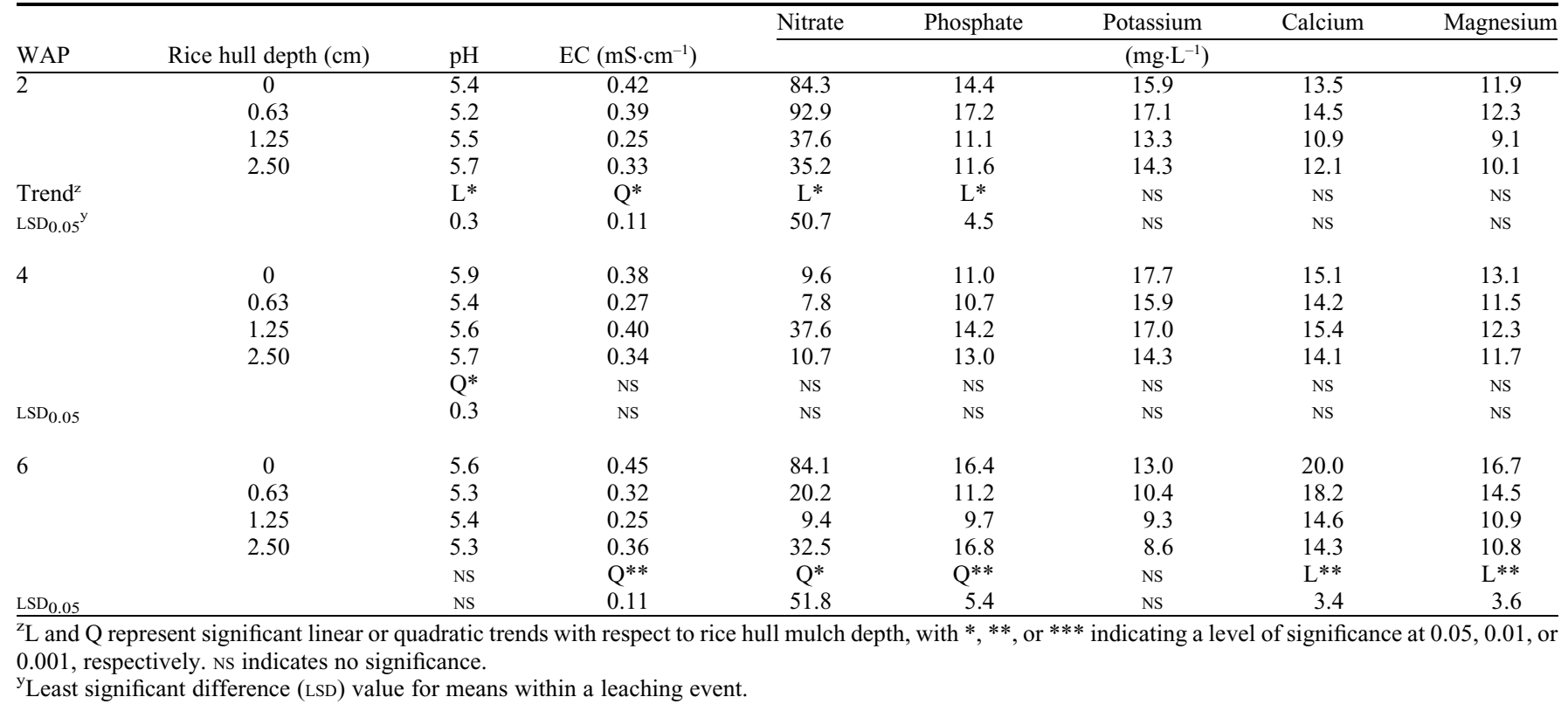

Table 3. Foliar nutrient concentrations in sunflower (Helianthus annuus 'Sunbright') grown in no. 3 containers covered with $0,0.63,1.25$, or $2.50 \mathrm{~cm}$ of parboiled rice hull mulch. Leaves were harvested six weeks after potting.

\begin{tabular}{|c|c|c|c|c|c|c|c|c|c|c|c|}
\hline & $\mathrm{N}$ & $\mathrm{P}$ & $\mathrm{K}$ & $\mathrm{Ca}$ & $\mathrm{Mg}$ & $\mathrm{S}$ & B & $\mathrm{Cu}$ & $\mathrm{Fe}$ & $\mathrm{Mn}$ & $\mathrm{Zn}$ \\
\hline Rice hull depth $(\mathrm{cm})$ & \multicolumn{6}{|c|}{$(\%)$} & \multicolumn{5}{|c|}{$\left(\mathrm{mg} \cdot \mathrm{kg}^{-1}\right)$} \\
\hline 0.63 & 5.34 & 1.02 & 3.28 & 2.81 & 0.86 & 0.92 & 114.8 & 16.5 & 142.1 & 336.6 & 104.9 \\
\hline 2.50 & 5.23 & 0.93 & 3.02 & 2.25 & 0.63 & 0.81 & 100.0 & 16.6 & 130.4 & 245.0 & 94.7 \\
\hline Trend $^{2}$ & NS & $\mathrm{L}^{* *}$ & $\mathrm{~L}^{* * *}$ & NS & $\mathrm{L}^{* *}$ & NS & NS & NS & NS & $\mathrm{L}^{*}$ & $\mathrm{~L}^{*}$ \\
\hline $\operatorname{LSD}_{0.05^{y}}$ & NS & 0.12 & 0.29 & NS & 0.18 & NS & 15.9 & NS & NS & 61.9 & NS \\
\hline
\end{tabular}

${ }^{\mathrm{z}} \mathrm{L}$ and $\mathrm{Q}$ represent significant linear or quadratic trends with respect to rice hull mulch depth, with *, ${ }^{* *}$, or *** indicating a level of significance at $0.05,0.01$, or 0.001 , respectively. NS indicates no significance.

${ }^{\mathrm{y}}$ Least significant difference (LSD) value for means within a leaching event. 
the experiment, despite the fertilizer solution containing $40 \% \quad \mathrm{NH}_{4}{ }^{+}-\mathrm{N}$. Niemiera and Wright (1987a) reported rapid nitrification in containers between 20 and $30{ }^{\circ} \mathrm{C}$, where application of $100 \mathrm{mg} \cdot \mathrm{L}^{-1} \mathrm{NH}_{4}^{+}$resulted in leachates with only $2-4 \mathrm{mg} \cdot \mathrm{L}^{-1} \mathrm{NH}_{4}{ }^{+}$in just $6 \mathrm{~d}$. Furthermore, based on $\mathrm{NO}_{3}{ }^{-}$accumulation rates in pine bark substrates, it has been projected that a $40 \mathrm{mg} \cdot \mathrm{L}^{-1} \mathrm{NH}_{4}^{+}$solution could be completely oxidized in $20 \mathrm{~h}$ (Niemiera and Wright, 1987b). Despite differences in water-extractable $\mathrm{NO}_{3}{ }^{-}$levels, foliar $\mathrm{N}$ in sunflower plants was similar in all treatments throughout the experiment (Table 3; data for 6 WAP only presented). Foliar $\mathrm{N}$ levels were within the recommended range of $5 \%$ to $6 \%$ (Whipker et al., 1998).

Water-extractable $\mathrm{PO}_{4}{ }^{3-}$ from substrates followed a similar trend to $\mathrm{NO}_{3}{ }^{-}$across the three harvest dates. Phosphate decreased with increasing $\mathrm{PBH}$ depth at $2 \mathrm{WAP}$, whereas there were no differences at 4 WAP. At 6 WAP, $\mathrm{PO}_{4}{ }^{3-}$ concentration decreased and then increased quadratically as $\mathrm{PBH}$ depth increased. The nonmulched control and those with $2.50 \mathrm{~cm}$ PBH had similar substrate $\mathrm{PO}_{4}{ }^{3-}$ concentrations, whereas those with $1.25 \mathrm{~cm}$ PBH had a lower $\mathrm{PO}_{4}{ }^{3-}$ concentration. Results from the filtrate experiment suggest that $\mathrm{PBH}$ are a source of $\mathrm{PO}_{4}{ }^{3-}$ and thus should increase water-extractable $\mathrm{PO}_{4}{ }^{3-}$ in the substrate (Figs. 1 and 2). The net increase in $\mathrm{PO}_{4}{ }^{3-}$ from $\mathrm{PBH}$ in the filtrate experiments generally ranged from 10 to $20 \mathrm{mg} \cdot \mathrm{L}^{-1}$, whereas the target $\mathrm{PO}_{4}{ }^{3-}$ concentration supplied in the irrigation stream was $66 \mathrm{mg} \cdot \mathrm{L}^{-1}$ (based on $\mathrm{N}$ application rates). Thus the increase in $\mathrm{PO}_{4}{ }^{3-}$ from the $\mathrm{PBH}$ was relatively small compared with the actual application rate of $\mathrm{PO}_{4}{ }^{3-}$, and did not manifest as large increases in substrate available $\mathrm{PO}_{4}{ }^{3-}$ concentrations when sunflowers were grown in PBH-mulched substrates. Foliar P decreased linearly with increasing $\mathrm{PBH}$ depth (Table 3), although in all treatments it was well above recommended tissue levels of $0.7 \%$ to $0.8 \%$ (Whipker et al., 1998).

Water extractable $\mathrm{K}$ concentration was similar across treatments at each harvest date (Table 2). Although the difference in $\mathrm{K}$ between mulched and nonmulched funnels was more pronounced in the filtrate experiments (Figs. 1 and 2), the lack of treatment effects in water-extractable $\mathrm{K}$ concentrations from the substrate in the sunflower study likely follows the same logic as provided for $\mathrm{PO}_{4}{ }^{3-}$. Foliar $\mathrm{K}$ concentration was similar at 2 and 4 WAP (data not shown); however, it decreased with increasing PBH mulch depth at 6 WAP (Table 3 ). Foliar K concentration at $6 \mathrm{WAP}$ was lower than recommended $(5.4 \%$ to $6.3 \%$, Whipker et al., 1998) in all treatments. A general purpose fertilizer was used in this experiment with macro-element ratio of $20 \mathrm{~N}-4.4 \mathrm{P}-16.6 \mathrm{~K}$. Whipker et al. (1998) suggest a high-K fertilizer regime with macro-element ratios of $20 \mathrm{~N}-2.5 \mathrm{P}-25 \mathrm{~K}$. Higher $\mathrm{P}$ and lower $\mathrm{K}$ supplied in this experiment resulted in higher than recommended foliar $\mathrm{P}$ concentrations and lower than recommended foliar $\mathrm{K}$ concentration.
Water-extractable Ca was similar across PBH depths at 2 and 4 WAP, but decreased linearly with increasing PBH depth at 6 WAP (Table 2). This trend follows what might be expected considering the depressed $\mathrm{Ca}$ concentration observed in funnel filtrates at $\mathrm{PBH}$ mulch depth increased (Figs. 1 and 2). Foliar $\mathrm{Ca}$ concentrations were similar regardless of mulch depth throughout the experiment. Subtle differences in filtrate or substrate $\mathrm{Ca}$ concentrations were not enough to affect foliar Ca levels.

Water-extractable $\mathrm{Mg}$ followed a trend similar to $\mathrm{Ca}$, in that substrate concentrations decreased linearly with increasing mulch depth at 6 WAP only (Table 3 ). This is the opposite of what would be expected considering the additional $\mathrm{Mg}$ released from $\mathrm{PBH}$ in the filtrate experiments (Figs. 1 and 2). As with other nutrients previously discussed, the difference in $\mathrm{Mg}$ concentration between mulched and nonmulched funnels in the filtrate experiment was relatively small compared with the $\mathrm{Mg}$ concentration applied via the irrigation stream. Foliar $\mathrm{Mg}$ also decreased linearly with increasing mulch depth, although all treatments had foliar $\mathrm{Mg}$ within or slightly above recommended concentrations (Whipker et al., 1998).

The objective of this research was to determine how PBH mulch affects the fertilizer nutrient concentration of irrigation water passing through the mulch layer, and its subsequent effect on plants. We measured subtle changes in the fertilized irrigation water immediately after it passed through the mulch layer. Parboiled rice hull mulch caused a temporary and slight decrease in $\mathrm{NO}_{3}{ }^{-}$and $\mathrm{NH}_{4}{ }^{+}$concentration. Phosphate and $\mathrm{K}$ concentrations generally increased with each irrigation event due to the relatively high concentrations of those elements in $\mathrm{PBH}$. Calcium and $\mathrm{Mg}$ exhibited an inverse relationship where the $\mathrm{PBH}$ mulch decreased $\mathrm{Ca}$ and increased $\mathrm{Mg}$ concentrations in the filtrates. Despite these measured differences, there were relatively few and minor differences in the nutrient concentration of the substrate. Furthermore, there were no measurable differences in sunflower growth or physical appearance (SPAD foliar chlorophyll), and only minor and inconsequential differences in plant nutrient status (and only at 6 WAP). In summary, although we were able to measure small changes in fertilized irrigation water because of the presence of PBH mulch, these changes had no meaningful effect on the growth or development of container-grown sunflower plants. Rice hull mulches are not likely to affect the nutrition of container-grown plants.

\section{Literature Cited}

Altland, J.E., J.K. Boldt, and C.R. Krause. 2016a. Rice hull mulch affects germination of bittercress and creeping woodsorrel in container plant culture. Amer. J. Plant Sci. 7:2359-2375.

Altland, J.E. and C.R. Krause. 2014. Parboiled rice hull mulch in containers reduces liverwort and flexuous bittercress growth. J. Environ. Hort. 32(2):59-63.
Altland, J.E. and M. Lanthier. 2007. Influence of container mulches on irrigation and nutrient management. J. Environ. Hort. 25:234-238.

Altland, J.E., J. Locke, and J.K. Boldt. 2016b. Pyrolysis temperature and heating time affect rice hull biochar properties. Acta Hort. (In press).

Broschat, T. 2007. Effects of mulch type and fertilizer placement on weed growth and soil $\mathrm{pH}$ and nutrient content. HortTechnology 17:174-177.

Chalker-Scott, L. 2007. Impact of mulches on landscape plants and the environment - A review. J. Environ. Hort. 25:239-249.

Cochran, D.R., C.H. Gilliam, D.J. Eakes, G.R. Wehtje, P.R. Knight, and J. Olive. 2009. Mulch depth affects weed germination. J. Environ. Hort. 27:85-90.

Dole, J.M. and H.F. Wilkins. 1999. Floriculture principles and species. Prentice Hall, Upper Saddle River, NJ.

Evans, M.R., J.S. Buck, and P. Sambo. 2011. The $\mathrm{pH}$, electrical conductivity, and primary macronutrient concentration of sphagnum peat and ground parboiled fresh rice hull substrates over time in a greenhouse environment. HortTechnology 21:103-108.

Ferguson, J., B. Rathinasabapathi, and C. Warren. 2008. Southern redcedar and southern magnolia wood chip mulches for weed suppression in containerized woody ornamentals. HortTechnology 18:266-270.

Gachukia, M.M. and M.R. Evans. 2008. Root substrate $\mathrm{pH}$, electrical conductivity, and maroelement concentration of sphagnum peat-based substrates amended with parboiled fresh rice hulls or perlite. HortTechnology 18:644-649.

Glenn, J.S., C.H. Gilliam, J.H. Edwards, G.J. Keever, and P.R. Knight. 2000. Recycled waste paper mulch reduces available container N. J. Environ. Hort. 18:188-191.

Mills, H.A. and J.B. Jones. 1996. Plant analysis handbook II. MicroMacro Publishing, Athens, GA.

Niemiera, A.X. and R.D. Wright. 1987a. Influence of temperature on nitrification in a pine bark medium. HortScience 22:615-616.

Niemiera, A.X. and R.D. Wright. 1987b. Influence of $\mathrm{NH}_{4}-\mathrm{N}$ application rate on nitrification in a pine bark medium. J. Amer. Soc. Hort. Sci. 111:616-618.

Penny, G.M. and J.C. Neal. 2003. Light, temperature, seed burial, and mulch effects on mulberry weed (Fatoua villosa) seed germination. Weed Technol. 17:213-218.

Ram, M., D. Ram, and S.K. Roy. 2003. Influence of an organic mulching on fertilizer nitrogen use efficiency and herb and essential oil yields in geranium (Pelargonium graveolens). Bioresour. Technol. 87:273-278.

Richardson, B., C.H. Gilliam, G.B. Fain, and G. Wehtje. 2008. Nursery container weed control with pinebark mini-nuggets. J. Environ. Hort. 26:144-148

Trinka, D.L. and M.P. Pritts. 1992. Micropropagated raspberry plant establishment responds to weed control practice, row cover use, and fertilizer placement. J. Amer. Soc. Hort. Sci. 117:874-880.

Warncke, D.D. 1986. Analyzing greenhouse growth media by the saturation extraction method. HortScience 21:223-225.

Whipker, B., S. Dasoju, and I. McCall. 1998. Guide to successful pot sunflower production. North Carolina State Univ. Hort. Info. Lflt. 562.

Wilen, C.A., U.K. Schuch, and C.L. Elmore. 1999. Mulches and subirrigation control weeds in container production. J. Environ. Hort. 17:174-180. 